\title{
【速報】
}

\section{幼児による粘土製作物における外形寸法の基礎的特徵 \\ Basic Characteristics of Exterior Dimensions of Clay Work Pieces Created by \\ Children in Nursery School}

\author{
依田光正 (正会員)* \\ Mitsumasa Yoda*
}

\begin{abstract}
Clay play is one of the most favorite activities of toddlers. This research intends to determine the basic characteristics of clay play work pieces created by children in nursery school. Work pieces were created by 18 to 35 -months-old nursery school children during four sessions of wheat flour clay play activity. Five boys and four girls participated in the activity. To determine the characteristics, exterior dimensions of 73 clay work pieces were precisely measured using a 3D measurement system. Cluster analysis (Ward method, square Euclid distance) was applied to the data. This enabled us to classify the data into five groups. Groups 1 and 2 account for $77 \%$ of the total, and they clarified the characteristics of the clay work pieces created. These groups would indicate characteristics of clay play work pieces of toddlers along to their development. The results suggest that these characteristics must be taken into consideration in the designing of toys or tools for toddlers.
\end{abstract}

\section{Key Words}

Children in nursery school, Wheat flour clay play, Work piece, Exterior dimensions, 3D measurement system

\section{1. はじめに}

幼児の日常生活の中で, 遊びは重要な位置を占めている. 遊 びでは身近にある玩具や用具等が用いられる場合が多い.しか しながら, どの様な玩具や用具が好まれているのか, 言語による コミュニケーション能力が十分に発達していない場合には, 行動 を通して推測する以外，その情報を得ることは難しい. しかしなが ら, 幼児の製作物の特徵を通して, 幼児が好む形状を知ることが 可能ではないだろうか. 幼児の遊びを通した製作活動に粘土製 作がある. そこで作られた製作物は, 幼児の好みや発達に伴った 形状の特徴を反映している可能性がある。 また, これまで幼児の

\section{2 年 3 月 16 日受理}

2012 年 7 月 19 日最終原稿受理

日本大学大学院理工学研究科医療・福祉工学専攻* 東京都千代田区神田駿河台 1-8-14

Graduate School of Science and Technology,

Department of Medical and Welfare Engineering,

Nihon University*

Kanda-Surugadai 1-8-14, Chiyoda-ku, Tokyo, Japan
製作した粘土製作物の形状を計測した報告は見られない. そこ で, 本報では幼児の製作物の精密な外形寸法を測定し，その特 徵を統計的に分類することを通して, 対象とした幼児の製作に対 する特性を明らかにすると共に, 幼児が使用する玩具や用具など のデザインなどへの応用可能性について検討することを目的とし ている.

本報では, 保育士の指示に従って, 自立して個々に製作がで きる年齢として1歳児から2歳児を本研究の対象とした. 特に, 1 歳児でも1歳6ヶ月からは手指の発達がめざましくなり, 砂場で力 ップなどを使って形を作ることや, 粘土遊びなどをたいへん好む ようになるとされている 1). 粘土遊びの中でも, 小麦粉粘土遊び で作製された製作物を, 本研究の研究対象とした. 小麦粉への アレルギーを十分確認してあれば，口に入れても問題はなく, 給 食材料である小麦粉を使用できるため低コストであることから, 比 較的頻繁に屋内活動のひとつとして実施されている.

協力いただいた保育園を通じて保護者には小麦粉粘土遊び の活動についての了解を得た. また, 保育園の看護師によって 小麦粉粘土あそびに参加する園児には小麦粉アレルギーがない ことを確認している. 製作物についても, 個人が特定されないよう にするなどの倫理的配慮をおこない, 研究以外には使用しないこ とを協力いただいた保育園に伝えて了解を得た. 


\section{2. 実験方法}

\section{1 実験手順}

製作物の計測データを得る過程を Fig.1に示す.協力いただ いた保育園において, 1歳から2歳児が屋内活動のひとつである 小麦粉粘土あそびで作成した製作物を取得する. 小麦粉粘土遊 びとは, 市販の小麦粉に水を適量加えて粘土状態にしたものに 少量の食紅などで色付けをした小麦粉粘土を用いて, 保育士の 指導と管理の下で園児が自由に作製遊びをおこなう活動をいう. 小麦粉粘土遊びの参加幼児は，1歳児クラスの男児5名と女児 4 名である.この9名が，6ヶ月間に4回実施した小麦粉粘土遊びで 製作をおこなった。遊びに参加した際の月齢は，18から35力月 である.これらの製作物を，3次元計測システムを用いて計測する ことによって, それぞれの3次元外形寸法データを取得した.

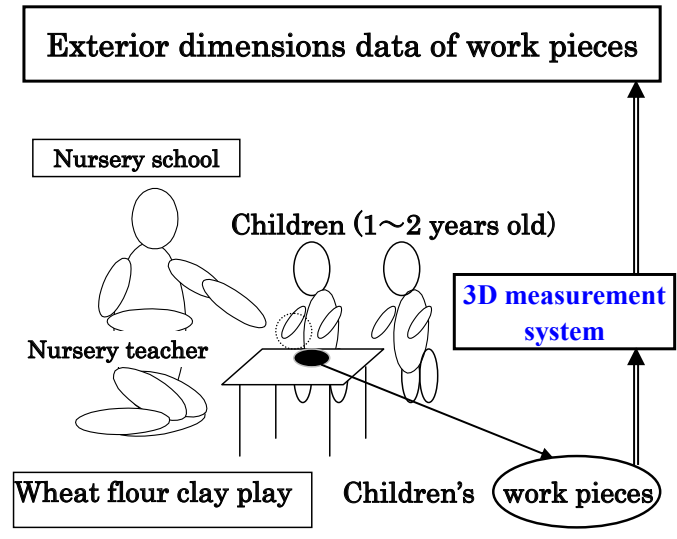

Fig.1 Process of obtaining 3D exterior dimension data of work pieces

\section{2 計測方法}

得られた製作物は，3次元計測システム (Roland DG MDX-15)を用いてスキャンピッチ $0.1 \mathrm{~mm}$ で3次元計測をおこな った. 収集されたばかりの製作物は, 小麦粉粘土が十分に硬化し ていないため, 本計測システムが採用している接触式の計測が 可能になるまで自然乾燥をおこなった.

乾燥による収縮の補正をおこなうために, 全製作物の体積の 平均值に近い22個の直方体を小麦粉粘土で製作し, 製作直後 の体積と乾燥後の体積を測定して比較した. 体積では, 平均して -16.56\%(SD 2.7)の収縮があった. そこで,この数值を用いて各 測定データに補正をおこなった.

\section{3. 実験結果}

\section{1 計測結果}

幼児が作った小麦粉粘土による製作物の一例を Fig.2 に示す. 小麦粉粘土遊びに参加した幼児によって, このような製作物を73 個得ることができた. 3次元計測システムを用いて計測した結果 に基づいて, Fig.2 の製作物を3次元表示した例を Fig.3 に示す. この3次元計測データから, 製作物底面の外周を抽出した結果を Fig.4 に示す. なお, この外周に囲まれた部分が底面積となる.

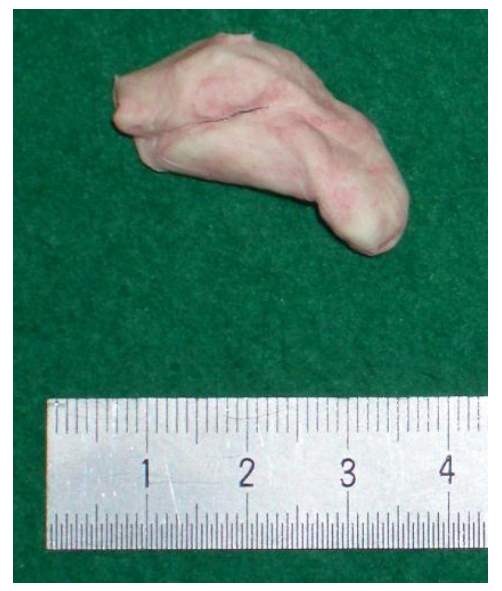

Fig.2 A sample work piece

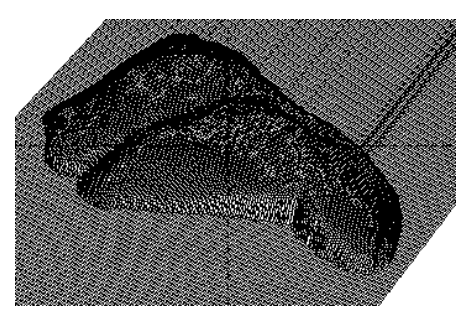

Fig.3 3D measurement data of a sample work piece

$(\mathrm{mm})$

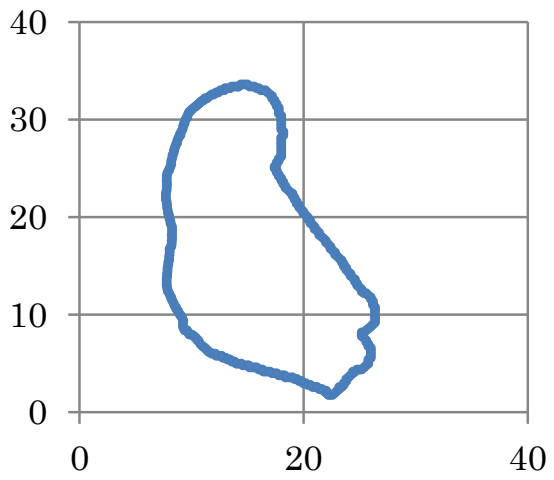

$(\mathrm{mm})$

Fig.4 Sample circumference of a work piece bottom

\section{2 結果の分析および考察}

各製作物をそれぞれの外周，底面積および体積のデータを用 いてグループ分けするために, Ward 法で各成分負荷を平方ユ ークリッド距離によるクラスター分析をおこなった. デンドログラム を項目間の距離の平均值 2.5 で区切ることによって5つのグルー プに分けられた. 以下，属する製作物の個数が多い順にグルー プ1からグループ5とした. 分析結果を, 外周と体積の関係で Fig.5 に示し, 外周と底面積の関係で Fig.6 に示寸. なお, クラス ター分析に際しては, 各製作物の外周, 底面積および体積を用 いているが, それぞれの数值のオーダーが異なるため, 外周, 底 面積および体積のそれぞれにおいて標準得点(Ave.0, SD1)に 変換して分析をおこなった. 
$\left(\mathrm{mm}^{3}\right)$

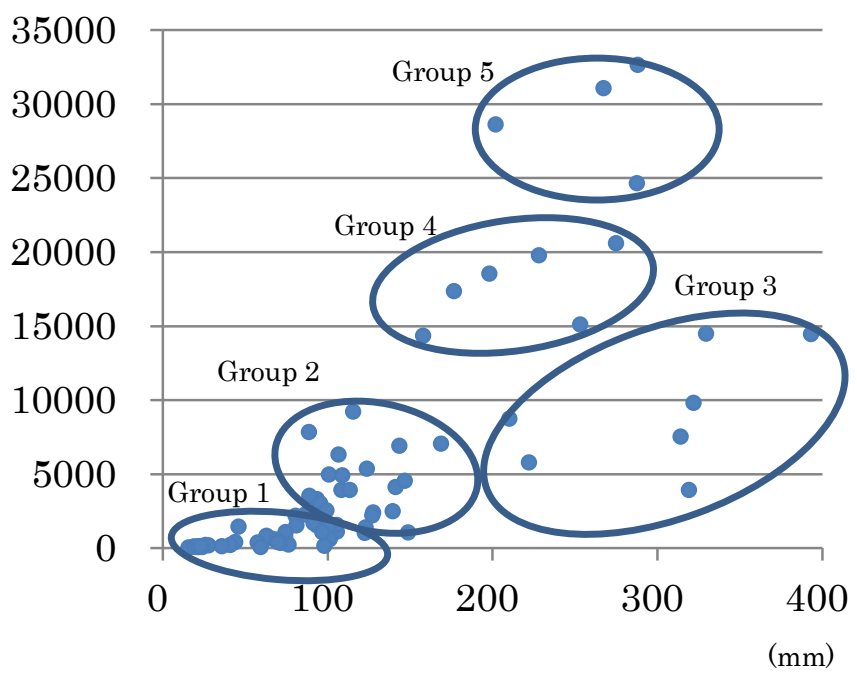

Fig.5 Cluster groups in relationship between circumference and cubic content

$\left(\mathrm{mm}^{2}\right)$

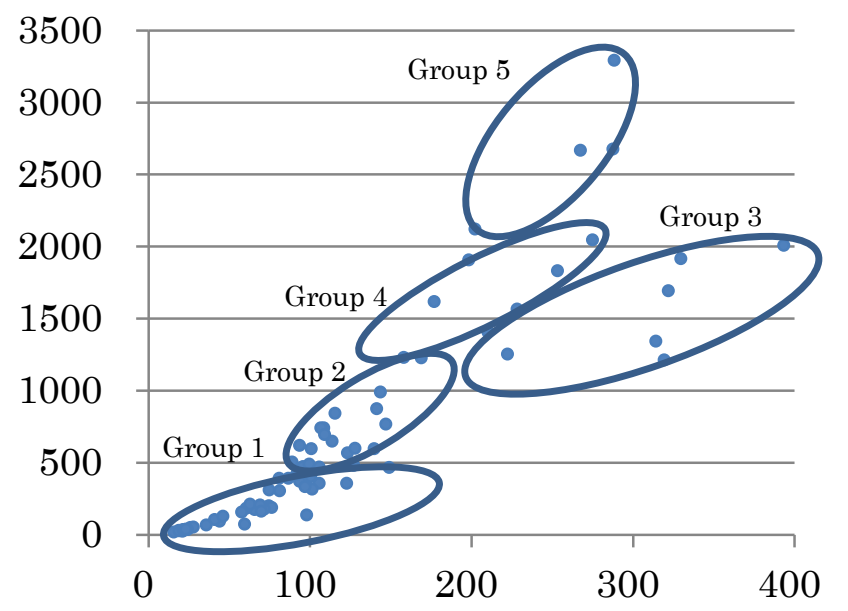

$(\mathrm{mm})$

Fig. 6 Cluster groups in relationship between circumference and bottom area

以下, 各グループの特徵について, 外周, 底面積および体積 の外形寸法と形状の特徵に着目した分析および考察について述 べる. 特に, 物体を扱うといら視点から体積に着目して外周や底 面積との関わりについて検討した.

(1)グループ1

このグループに属する製作物は 37 個で全製作物の $51 \%$ であ った.このグループで体積が最小と最大の製作物の外形寸法を Table 1 に示す. なお, このグループでの最小の体積の製作物は 全製作物の中での最小となる.このグループに属する製作物の 例を Fig.7 に示寸. 外周の最小值 $16.0 \mathrm{~mm}$ から,この製作物の 外形を円形と仮定すれば直径は $5.1 \mathrm{~mm}$ となり, 幼児が製作でき る最小の大きさが示唆される.

Table 1 Exterior dimensions data of minimum and

maximum cubic content work pieces in group 1

\begin{tabular}{|l|r|r|r|}
\hline \multicolumn{1}{|c|}{ グループ1 } & 外周 $(\mathrm{mm})$ & 底面積 $\left(\mathrm{mm}^{2}\right)$ & 体積 $\left(\mathrm{mm}^{3}\right)$ \\
\hline 体積最小 & 16.0 & 16.4 & 28.3 \\
\hline 体積最大 & 86.8 & 389 & 2258 \\
\hline
\end{tabular}

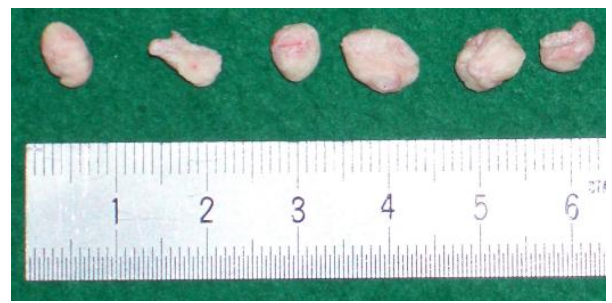

Fig.7 Samples of work pieces in group 1

(2)グループ2

このグループに属する製作物は19個で全製作物の $26 \%$ であ った.このグループで体積が最小と最大の製作物の外形寸法を Table 2 に示す. また, これらの製作物を Fig.8に示す. 本グルー プの製作物には, グループ1で示した形状がそのまま拡大したよ うな傾向を示すとともに，何らかの形を表現するような特徴ある形 状を示す傾向も見られた.

Table 2 Exterior dimensions data of minimum and maximum cubic content work pieces in group 2

\begin{tabular}{|l|r|r|r|}
\hline \multicolumn{1}{|c|}{ グループ2 } & 外周 $(\mathrm{mm})$ & 底面積 $\left(\mathrm{mm}^{2}\right)$ & 体積 $\left(\mathrm{mm}^{3}\right)$ \\
\hline 体積最小 & 149 & 462 & 1037 \\
\hline 体積最大 & 115 & 837 & 9198 \\
\hline
\end{tabular}

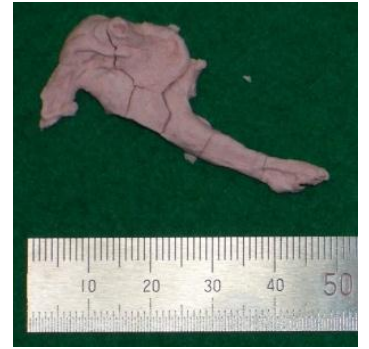

(Minimum cubic content)

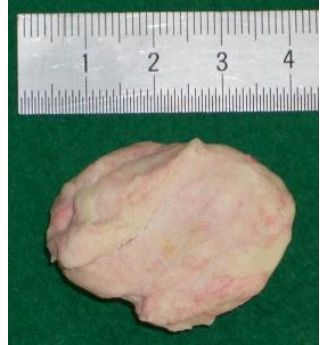

(Maximum cubic content) Fig. 8 Samples of work pieces in group 2

\section{(3)グループ3}

このグループに属する製作物は7個で全製作物の $10 \%$ あ゙あっ た.このグループで体積が最小と最大の製作物の外形寸法を Table 3に示す. また, これらの製作物を Fig.9に示す. 本グルー プでは, Fig.6 および Fig.7 に示されるように, 体積はあまり大きく ないが平面的に広がるような形状となる傾向を示すとともに, グル ープ1および 2 に属する程度の大きさの製作物を組み合わせて製 作する方法を用いる傾向が見られた. 
Table 3 Exterior dimensions data of minimum and maximum cubic content work pieces in group 3

\begin{tabular}{|l|r|r|r|}
\hline \multicolumn{1}{|c|}{ グループ3 } & 外周 $(\mathrm{mm})$ & 底面積 $\left(\mathrm{mm}^{2}\right)$ & 体積 $\left(\mathrm{mm}^{3}\right)$ \\
\hline 最小体積 & 319 & 1210 & 3916 \\
\hline 最大体積 & 329 & 1911 & 14465 \\
\hline
\end{tabular}

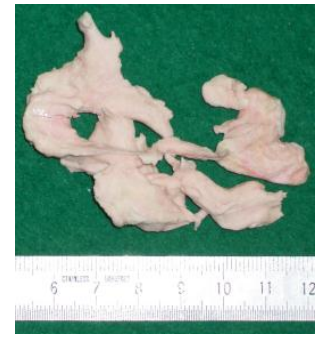

(Minimum cubic content)

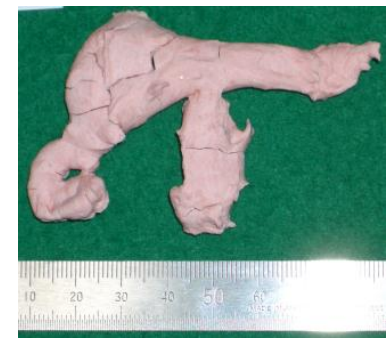

(Maximum cubic content) Fig.9 Samples of work pieces in group 3

(4)グループ4

このグループに属する製作物は6個で全製作物の $8 \%$ であっ た.このグループで体積が最小と最大の製作物の外形寸法を Table 4 に示す. また, これらの製作物を Fig.10 に示す. 本グル 一プでは，より大きな製作物を製作する傾向がみられ，その製作 も大きな塊から形作られる傾向が見られた.

Table 4 Exterior dimensions data of minimum and maximum cubic content work pieces in group 4

\begin{tabular}{|l|r|r|r|}
\hline グループ 4 & 外周 $(\mathrm{mm})$ & 底面積 $\left(\mathrm{mm}^{2}\right)$ & 体積 $\left(\mathrm{mm}^{3}\right)$ \\
\hline 最小体積 & 158 & 1226 & 14328 \\
\hline 最大体積 & 275 & 2042 & 20575 \\
\hline
\end{tabular}

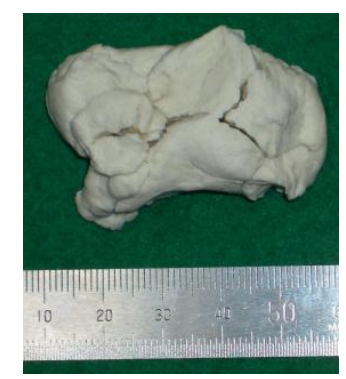

(Minimum cubic content) (Maximum cubic content) Fig.10 Samples of work pieces in group 4

\section{(5)グループ5}

このグループに属する製作物は最も少ない 4 個で全製作物の $5 \%$ あっった.このグループで体積が最小と最大の製作物の外形 寸法を Table 5 に示す.なお,このグループでの最大体積の製 作物は全製作物の中での最大体積となる. また, これらの製作物 をFig.11に示す. 本グループでは, 当該幼児として最も大き製 作に取り組んだ傾向が見られるとともに, 大きな塊から具体的な 形(「さかな」のような形など)を製作する傾向が見られた.このよう
に, 1歳児クラスにおいて, 一部ではあるが比較的大きな塊から 具体的な概念を形にすることができたのは, 比較的発達段階が 高い幼児である可能性を示している.このような特徴が見られたこ とを考慮すると,このグループの製作物サイズを用いて1歳から 2 歳児を対象とした玩具や用具をデザインする際には，具体的な 形の要素を盛り込む必要性が示唆された.

Table 5 Exterior dimensions data of minimum and

maximum cubic content work pieces in group 5

\begin{tabular}{|c|r|r|r|}
\hline グループ5 & 外周 $(\mathrm{mm})$ & 底面積 $\left(\mathrm{mm}^{2}\right)$ & 体積 $\left(\mathrm{mm}^{3}\right)$ \\
\hline 最小体積 & 287 & 2674 & 24623 \\
\hline 最大体積 & 288 & 3288 & 32628 \\
\hline
\end{tabular}

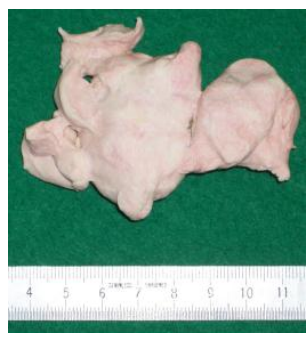

(Minimum cubic content)

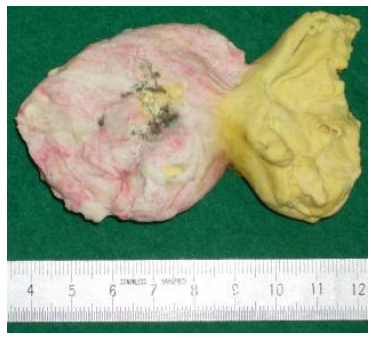

(Maximum cubic content)
Fig.11 Samples of work pieces in group 5

\section{4. おわりに}

1歳から2歳の幼児らが作製した製作物の外形寸法を測定し, 統計的に分析することによって5つのグループ分けをおこない, 製作物の基礎的特徴の概略を明らかにすることができた. 分析に よってグループ1と2で全体の $77 \%$ を説明していることが明らかに なり, 該当する幼児の粘土製作物の特徴を示していた. 全体とし ては, グループ1および2を基本の製作物として, 平面的な広がり の特徴を有するグループ3, 体積が増加する傾向を示したグルー プ4, さらに具体的な形を表そうとしたグループ5の傾向が見られ た. 5つのグループは幼児の発達に伴う特徵, および幼児の遊具 や用具をデザインする際に考慮す心゙き視点を示唆している. 今 後の課題として, グループ1およびグループ2の外形寸法を参考 にした凹凸のあるデザインなどを玩具などに適用した場合, 幼児 へ与える影響などを検討することが考えられる. また，明らかにな った外形寸法の基礎的特徵をもとに, 発達との関係についての 分析を進めることも重要な課題である.

本研究は財団法人精密測定技術振興財団の助成金事業の支 援を受けておこなわれたことに対して謝意を表します。

\section{参考文献}

1)菊池秀範, 鈴木みゆき, 原敏子, 石井美晴, 荒木敏, $0 \cdot 1 \cdot 2$ 歳 児の運動あそび, 初版, 東京; 萌林書林, 2005, 120-121. 